\title{
Comparative evaluation of physico-chemical and functional properties of different varieties of cowpea
}

\author{
- C.K. BHOKRE AND A.A. JOSHI*
}

Department of Food Chemistry and Nutrition, Coordinated Research Project on Arid Legume, College of Food Technology, Vasantrao Naik Marathwada Krishi Vidyapeeth, PARBHANI (M.S.) INDIA

Email : Joshianuprita.2009@rediffmail.com

*Author for Correspondence

Research chronicle : Received : 23.06.2015; Revised : 09.04.2016; Accepted : 23.04.2016

SUMMARY :

Cowpea, like other grain legumes is an important foodstuff in tropical and subtropical countries. The seeds of seven varieties i.e. Phule-CP-05040, CPD-150, CPD-115, GC-901, GC-909, CPD-132 and NBC-2, of cowpea obtained from AICRP on Arid legumes at Parbhani Center were assessed for their physico-chemical and functional properties to assess their potential use in the food industry. The seeds of genotype NBC-2 were longer and high in 100 -seed weight and density as compared to others. The CPD- 150 having highest bulk density $(0.769 \mathrm{~g} / \mathrm{ml})$ and CPD- 132 have maximum porosity $(48.55 \%)$. The protein content of different genotypes was in the range 20.58 to 28.91 per cent and genotype CPD-115 recorded highest in carbohydrate (58.10\%) and fat (3.99\%). Fibre content of all the varieties ranged between $3.01-4.80$ per cent. The cooking time for all the varieties was recorded as 35 to 44 min with CPD-115 had the shortest cooking time. In functional properties of cowpea genotypes the swelling capacity, hydration capacity, water and oil absorption capacities were in the range of 0.07 to $0.22 \mathrm{ml} / \mathrm{seed}, 0.078$ to $0.178 \mathrm{~g} / \mathrm{seed}, 1.29$ to $2.45 \mathrm{~g} / \mathrm{g}, 0.44$ to $2.36 \mathrm{~g} / \mathrm{g}$, respectively. Genotype CPD-150 had highest foaming capacity (24.0ml), foaming stability (20.0 min), emulsifying activity (24.0min) and emulsifying stability $(29.57 \mathrm{~min})$, respectively. Invitro protein digestibility of cowpea genotypes varied in between 80.60 to 89.27 per cent.

KEY WORDS : Cowpea, Physico-chemical properties, Functional properties, IVPD, Swelling capacity, Hydration capacity

How to cite this paper: Bhokre, C.K. and Joshi, A.A. (2016). Comparative evaluation of physico-chemical and functional properties of different varieties of cowpea. Internat. J. Proc. \& Post Harvest Technol., 7 (1) : 29 -

35. DOI: 10.15740/HAS/IJPPHT/7.1/29-35 